\title{
FEW INTERESTING BASIDIOMYCETES FUNGI FROM NAGPUR DISTRICT OF MAHARASHTRA, INDIA
}

\section{A. A. FULZELE}

Head, Department of Botany, S.M. Mohota College of Science, Nagpur, India. Corresponding Author Email : ashwajitfulzele@gmail.com

\section{ABSTRACT}

Tropical forests are the cradle of biodiversity and India is one of the mega diversity centers of the world, because of its tropical forests. Nagpur district is surrounded by tropical dry deciduous forest. Fungal diversity is astonishing in the forest areas of Nagpur district. Basidiomycota is the most interesting division of fungal kingdom, known for its food value, medicinal importance and beautiful forms and diversity. Though dominance of Basidiomycetes fungi is in subtropical and temperate region, but tropical areas like, in this part of India also shows good representation of this class of fungi which covers almost all orders of this class. Some of the morphologically interesting Basidiomycetes fungi identified from Nagpur district of India are explain here, for example-, Calocera sp., Clavaria sp., Cyathus striatus, Phallus indusiata, Geastrum spp., Hygrocybe coccineocrenata, Lycoperdon sp., Sparassis crispa, Tolustoma brumale, Tremella mesenterica, Geastrum fimbriatum, Hydnellum peckii, Lycoperdon sp; Mutinus caninus, Pulcherricium caeruleum, etc.

Key words: Fungi, Basidiomycetes, Nagpur.

\section{INTRODUCTION:}

Recently mycologists are taking interest to explore an interesting group of fungi Basidiomycetes. It has been established that this class of fungi is potentially a very economical group known for its food value earlier. Pharmaceutical scientists have discovered many bioactive compounds, like cytotoxic effect important in cancer treatment, antioxidants, antiviral, antifungal compounds from Basidiomycetes fungi, (Gu C. Q. et al 2007, Parino, F. et al 1999). Over 31515 species of Basidiomycetes fungi are known to us (Moore, 1980) Phylogenetic classification given by Blackwell et al 2006. Tropical forests are cradles of fungal diversity as well. There are many species which are industrial, medicinal as well as nutritive values are still not discovered. More explorations are needed for this group of fungi. Nagpur district is having good natural tropical forest towards south end of Satpura ranges with flow of perennial rivers and also this area is called as Tiger capital of world; keeping this aspect in view present work is carried out to understand diversity of Basidiomycetes fungi from forest 
of Nagpur district India. Many morphologically interesting fungi identified from this region have been explained here.

\section{MATERIALS AND METHODS:}

Population of Basidiomycetes fungi was dominant in monsoon season from July to August months; samples were collected, photographed and identified in the laboratory. Identification of fungi carried out with the help of standard literature like, Pegler and spooner (1992), Rinaldi and Tyndalo (1974), Garnweidner (1996), Pacioni (1981) and various sites available for fungi identifications.

\section{OBSERVATIONS:}

Following Basidiomycetes fungi have been identified from forest of Nagpur region

\section{Table No. 1: List of the Basidiomycetes fungi isolated from Nagpur} District.

\begin{tabular}{|c|c|c|c|}
\hline S.No. & Names of the Fungi & S.No & Names of the Fungi \\
\hline 1 & Agaricus sp. & 39 & Leucocoprinus cepaestipes \\
\hline 2 & Auricularia auriculajudae & 40 & Lycoperdon sp. \\
\hline 3 & Calocera sp & 41 & Marasmius androsaceus. \\
\hline 4 & Cantharellus sp. & 42 & Marasmius ramealis \\
\hline 5 & Clavulina cristata, & 43 & Marasmius perforans \\
\hline 6 & Clavulina rugosa & 44 & Marasmius rotula \\
\hline 7 & Clitocybe sp. & 45 & Microlepiota sp. \\
\hline 8 & Clitocybe langei & 46 & Mycena epipterygia \\
\hline 9 & Collybia butyraceae & 47 & Mycena pura \\
\hline 10 & Collybia sp. & 48 & Mutinus caninus \\
\hline 11 & Coltricia sp. & 49 & Naematoloma sp. \\
\hline 12 & Coniphora sp. & 50 & Nyctalis sp. \\
\hline 13 & Coprinus comatus & 51 & Onnia tomentosa \\
\hline 14 & Coprinus xanthotris & 52 & Osmoporus sp. \\
\hline 15 & Cortinarius sp. & 53 & Oudemansiella mucida \\
\hline 16 & Crepisotus mollis & 54 & Oudemansiella sp. \\
\hline 17 & Cyathus striatus & 55 & Phallus indusiata \\
\hline 18 & Cyptotrama sp. & 56 & Piptoporus sp. \\
\hline 19 & Dentinum sp. & 57 & Pisolithus tinctorius \\
\hline 20 & Entoloma sp. & 58 & Plolyporus Squamosus \\
\hline 21 & Fomitopsis sp. & 59 & Plurotus sp. \\
\hline 22 & Ganoderma lucidum & 60 & Polyporus mori \\
\hline 23 & Ganoderma tsugae & 61 & Polyporus sp. \\
\hline 24 & Geastrum fimbriatum & 62 & Pulcherricium caeruleum \\
\hline
\end{tabular}




\begin{tabular}{|l|l|l|l|}
\hline 25 & Gloeophyllum sepiarium & 63 & Pycnoporus cinnabarinus \\
\hline 26 & H. coccineocrenata & 64 & Ramaria sp. \\
\hline 27 & Hygrocybe coccinea & 65 & Schizophyllu commune \\
\hline 28 & Hericium sp. & 66 & Serpula sp. \\
\hline 30 & Hydnellum peckii & 67 & Sparassis crispa \\
\hline 31 & Hygrocybe coccinea & 68 & Stereum sp. \\
\hline 32 & Inocybe sp. & 69 & Tolustoma brumale \\
\hline 33 & L. clypeolaria & 70 & Traetes bersicolor \\
\hline 34 & Laccaria sp. & 71 & Tricholoma sp. \\
\hline 35 & Lactarius sp. & 72 & Tricholomopsis sp. \\
\hline 36 & Lapiota Cristata & 73 & Tremella mesenterica \\
\hline 37 & Lenzites sp. & 74 & Tyroyces sp. \\
\hline 38 & Pulcherricium caeruleum & 75 & Tyroycs sp. \\
\hline
\end{tabular}

Morphological characteristics and habitat of the collected Basidiomycetes fungi.

\section{Auricularia auriculajudae}

Fruit body: a distinctive species recognized by the gelatinous, ear-shaped fruit bodies growing on dead wood. $3-10 \mathrm{~cm}$ across, at first cup-shaped, soon widely spreading over the substratum, with deflexed, undulating, bracket-like portions. Upper surface pale grayish or whitish, shaggy with dens, whitish hairs, concentrically zoned. Fertile surface reddish purple, often with a whitish bloom, smooth, veined. Flesh firm, gelatinous, horny when dry. Spore deposit white.

Habitat and distribution: found on stumps and logs of deciduous trees, common in near Pench forest.

\section{Cyathus striatus}

Fruit body: Shaped like an inverted cone when young; dark red -brown, with hairy, bristly surface which is leathery and tough; covered with a white skin before maturity; when skin tears it reveals the brownish-grey 'nest' part of the fungus with several egg-shaped ; peridioles (spore containers); 1- 
$1.5 \mathrm{~cm}$ in diameter.

Habitat and distribution: Decaying wood among leaf litter on forest floors; frequent, in Chorbahuli, Pench and Satnavari forest in the Nagpur district

\section{Geastrum fimbriatum}

Fruit body: Initially spherical and growing underground. Its outer cover which is grayish -white and 1-2 $\mathrm{mm}$ thick, eventually opens, tearing from the margins and dividing into up to many triangular lobes. During this process the fungus is raised above the ground and lies, in a typical star shape loosely on the surface. The lobes roll back even more when fungus is old. Open, the fungus reveals its spherical spore-sac. Inside it develops a first white spore mass which discolors with age and becomes a grayishbrown spore dust. At the apex of the spore-sacisa fringed, warty opening serving for spore dispersal

Habitat and distribution: In small groups in moist with good humus in soil in Satnavari forest. The earth star is among the most curious organisms in nature. Fairly rare, they are not eaten, however not poisonous.

\section{Tolustoma brumale:}

Fruit body: Spherical with a long stalk, light straw- coloured when young, later pale ochre, with minute scales, and a narrow, downward directed ring at the point of stem insertion; a pointed opening arises from a brownishblack zone at the top; to $1.2 \mathrm{~cm}$ in diameter.

Stem: Pale grey; somewhat scaly, hollow and with small tubers at its base up to $6 \mathrm{~cm}$ long and $3 \mathrm{~mm}$ in diameter.

Habitat and distribution: Rare, found in Satnavari forest in during month of August in sunny spot. 
Phallus indusiata :

Fruit body: Egg up to $4 \mathrm{~cm}$ in diameter, globose, ovoidal, white or grayish, carpophores $15-20 \times 2.5-3.5 \mathrm{~cm}$, fusiform or cylindrical. Barbed toward the top, white, porous, hollow, head ogival for a short time, then bell-shaped, yellowish under the gleba, white if stripped, with rugose surface, reticulate with apex perforated and delimited by a raised and distinct collar. Veil white, hanging almost to the ground, with wide polygonal chains formed by elliptical strands. Gleba olive-green, mucilaginous, not verified.

Habitat and distribution: Found in the area of Pench forest under Bamboo plants during July - August.

\section{Tremella mesenterica :}

Fruit body: Emerging as small nodules from tree bark when young, later folded irregularly like a brain, bright golden yellow, sometime white and pruniose when young; soft like jelly and becoming a shapeless mess when old; up to $5 \mathrm{~cm}$ high and just as wide.

Habitat and distribution: Mainly in monsoon on dead branches of trees, frequent.

\section{Hydnellum peckii}

Fruit body: Cap at first slightly club-shaped. Later funnel-shaped, with weakly circular zonation; white when young, minutely fealty and with blood-red drops of water, later discoloring to rust- to- grey- brown, margin stays pale for the longest; very hard to $6 \mathrm{~cm}$ in diameter.

Spines: first white, later dirty brownish and hard. Stem: Short, very tough and firm, minutely fealty when you nag of irregular shape.

Flesh: Soft and spongy at first, a blood-red, watery sap exudes when 
pressure is applied later dirty flesh-brown; woody and very tough.

Habitat and distribution: mostly in groups in forest near Kuwarabhivsen, near mountainous regions, rather rare.

\section{Mutinus caninus}

Fruit body: a small delicate stinkhorn, with a white or pale yellow with a mycelia crown at base, Egg $2-4 \mathrm{~cm} \times 1-2.5 \mathrm{~cm}$ broken at apex into 3-2 lobes, ovoid-elongated or pear shaped. Carpophores 6-15 cm x $1 \mathrm{~cm}$, cylindrical hollow, first whitish then tinged with orange or faintly pinkish, slightly orange at apex when mature, fertile part beneath gleba bright red, sometimes perforated at top, ogival, $2 \mathrm{~cm}$ high, reticulate with deep, large cells. Gleba green and mucous, slightly fetid, Flesh cellular, fragile.

Habitat and distribution: In humus-rich ground rich in ligneous fragments in damp part of Bamboo plantation. During August month near Chorbahuli forest.

\section{Hericium sp.}

Fruit body: Branching like coral, with horizontally extending branches which are splits into short twigs, with bundle of long, pointed downwards pointing spines at their tips, pure white for long time, only at extreme age becoming cream or brownish; staying fresh for several weeks, up to $15 \mathrm{~cm}$ broad,

Habitat and distribution: on thick, dead tree trunks, rather rare. Found in Satnavari forest.

\section{Microtyphula sp.}

Fruit body: Very thin and slender; usually unbranched. Occasionally with abortive branches at the base; smooth hollow, pale brownish, fibrous and 
fealty at the base, up to $5 \mathrm{~cm}$ high, but only $1-3 \mathrm{~mm}$ thick.

Habitat and distribution: In forest litter during monsoon season found in Pench.

\section{Clavulina rugosa}

Fruit body: $2-3$ in $/ 5-8 \mathrm{~cm}$ tall, forming one or more clubs, $0.5-1 \mathrm{~cm}$ in diameter, whitish or with a yellowish tint, flattened, with a few vertical wrinkles or ridges, fragile. Spore deposit white.

Habitat and distribution: found on bare soil in Pench forest.

\section{Clavulina cristata}

Fruit body: 2-7 $\mathrm{cm}$ in diameter, densely branched, white with individual branches terminating as crest-like base. Flesh white, soft. Spore deposit white,

Habitat and distribution: found on leaf litter and bare soil in Pench forest.

\section{Pulcherricium caeruleum}

Fruit body: An easy to recognize parchment-fungus, owing to the striking, bright blue colours. $3-8 \mathrm{~cm}$ in diameter, crust-like about $0.5 \mathrm{~mm}$ thick, more or less circular but neighboring fruit bodies may become joined, surface bright indigo blue or darker at the centre, with the margin lifted in older specimens. Fleshy membranous, soft and waxy. Spore deposit whitish.

Habitat and distribution: On underside of rotting branches from Satnavari forest.

\section{Sparassis crispa}


Fruit body: a large fungus, resembling a cauliflower, with many short, wavy branches, found growing at the base of pine trees.10-40 cm diameter, cauliflower-like, whitish to cream coloured finally brownish, with numerous, flat, ribbon-like branches, $1-2 \mathrm{~cm}$ broad, wavy and leaf-like, arising from a stalk-like base, flesh white, thin, tough, with a sweetish odour, spore deposit cream colored,

Habitat and distribution: Forest litter from Pench prakalp

\section{Hygrocybe coccinea}

Fruit body: It show distinguished bright red cap, gills and stem. Cap 3-5 $\mathrm{cm}$ diameter, conical then expanding, blood-red to pinkish orange, smooth. Gills adnate, red to yellowish orange, thick, broad, moderately crowded. Stem .5- $1 \mathrm{~cm}$, cylindrical, scarlet-red, paler at the base, hollow, smooth. Flesh thin, yellow, watery. Spore deposit white.

Habitat and distribution: Collected from forest litter of Pench forest.

\section{Lapiota cristata}

Fruit body: Cap- Bell-shape when young, soon convex or flat, apex dark red to brownish-black, and with small, dark brown scales arranged in circles on a white background towards the margin. Gills- white; crowded, spore white.

Habitat and distribution: collected from litter of Chorbahuli forest. 
International Journal of Researches in Biosciences, Agriculture \& Technology
September 2013 Issue-1, Volume-1
ISSN No. (Online): 2347-517X

PLATE 1 : BASIDIOMYCETES FUNGI FROM NAGPUR DISTRICT

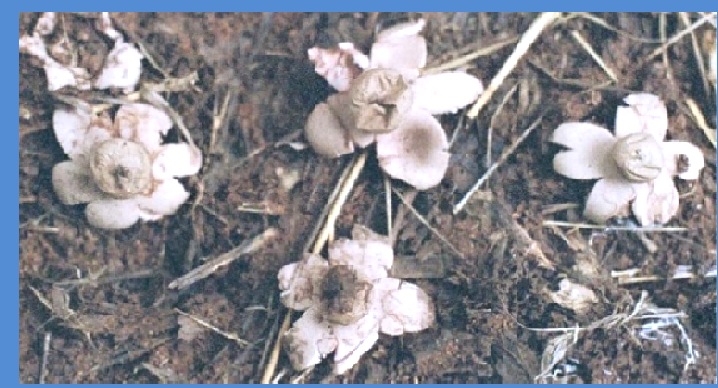

A: Geastrum fimbriatum

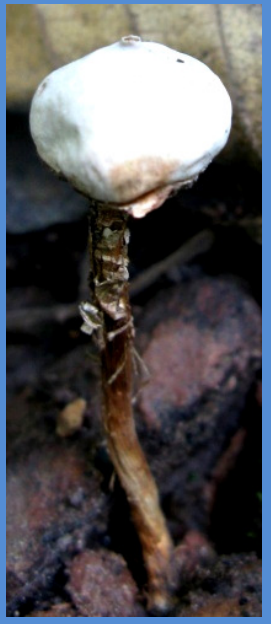

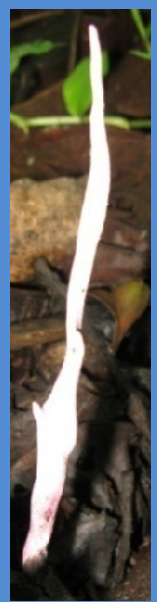

2: sp

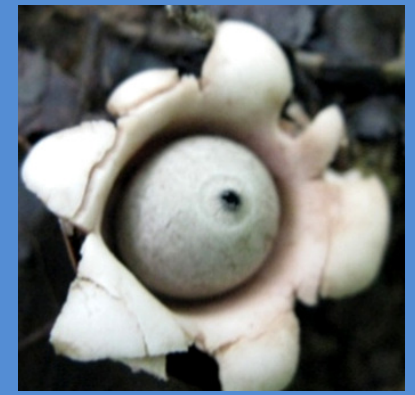

B:

fimbriatum

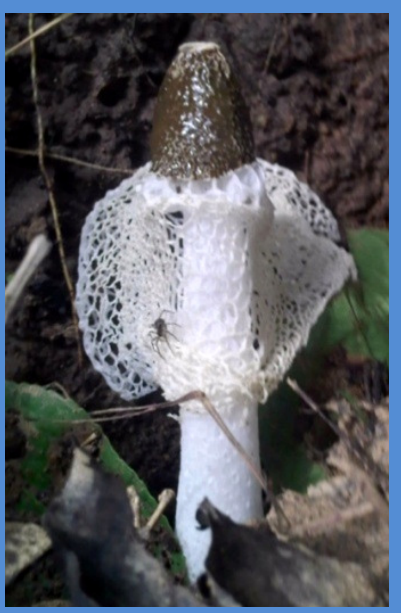

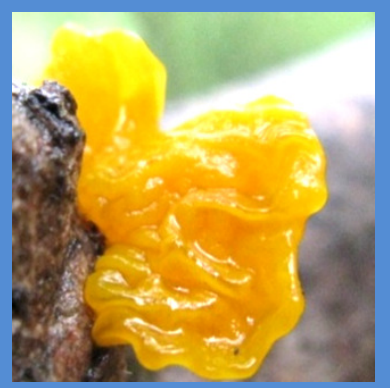

C:Tremella mesenterca

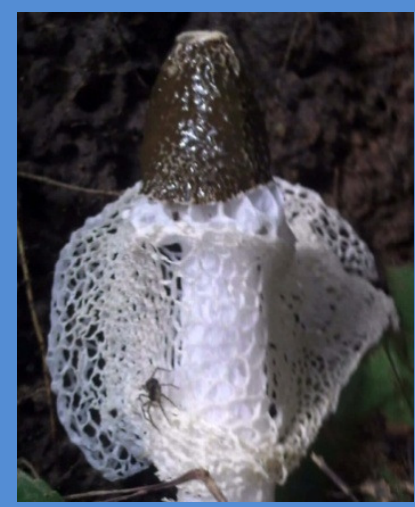

3': indusiata

\section{3: Phallus indusiata}

Phallus brumale
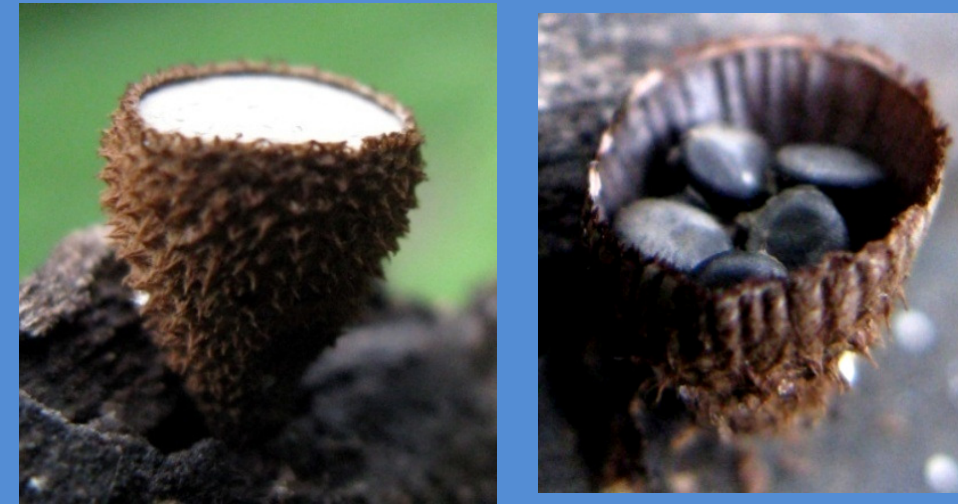

4': Cyathus striatus

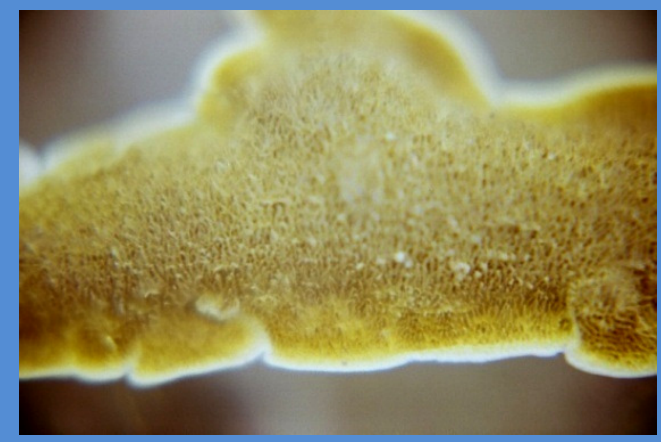

5: : unknown 
International Journal of Researches in

September 2013

ISSN No. (Online): Biosciences, Agriculture \& Technology Issue-1, Volume-1

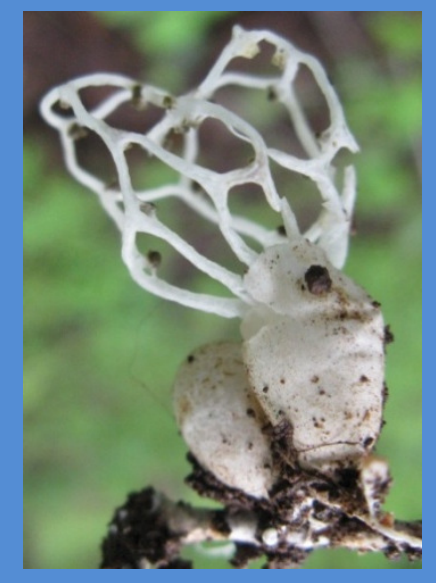

6: Ileodictyon sp.

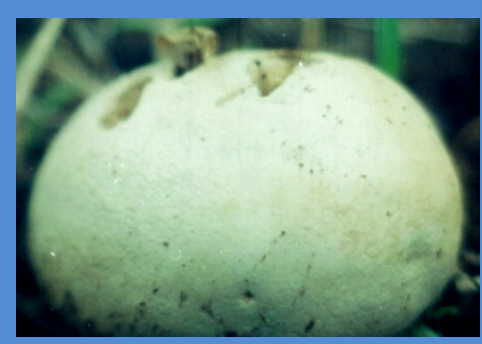

8: Lycoperdon sp.

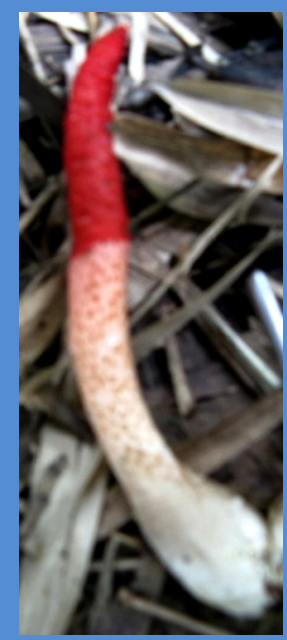

11: Mutinus canin
9: Lycoperdon sp.

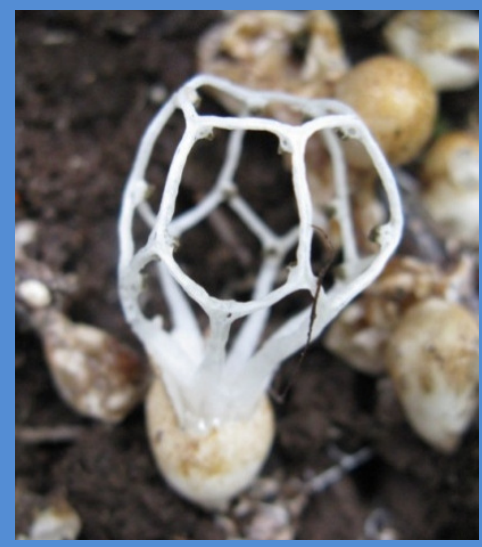

6': Ileodictyon sp.
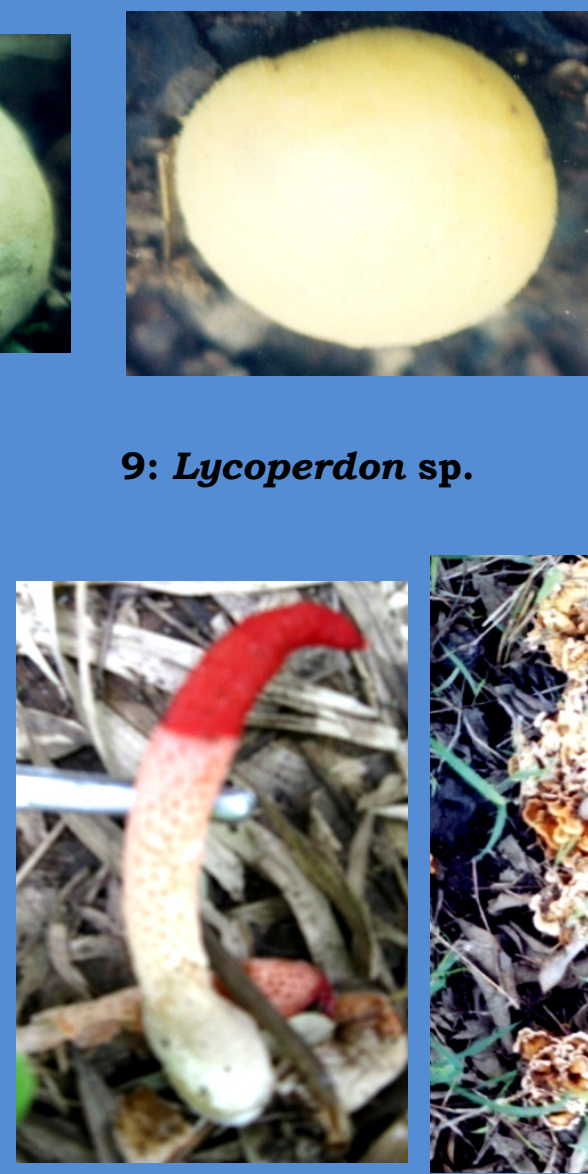

11': canin

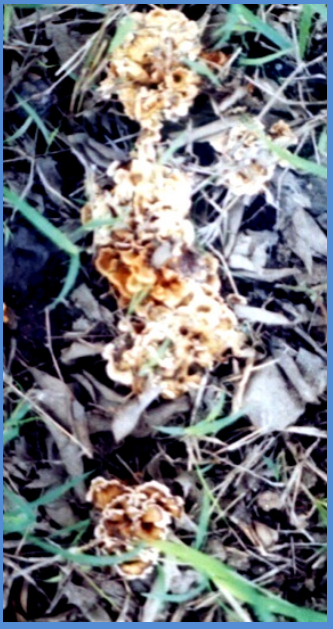

Mutinus 12 crispa

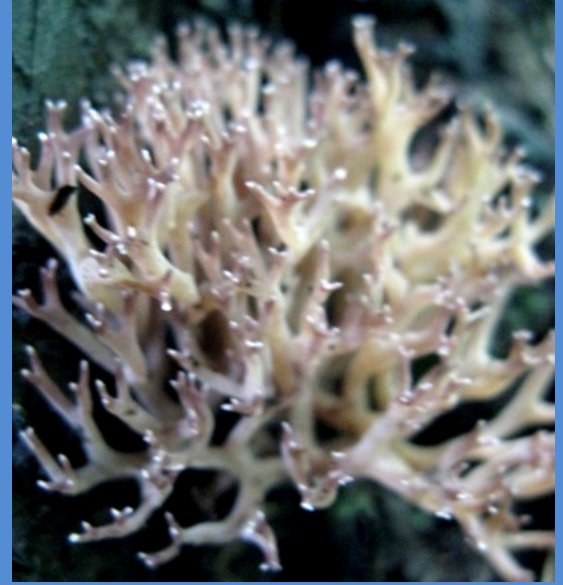

7: Clavaria sp.

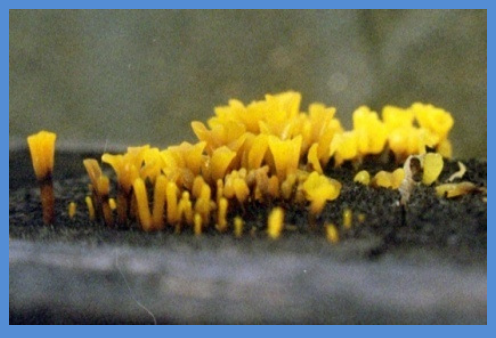

10:

Dacryopinax spathularia

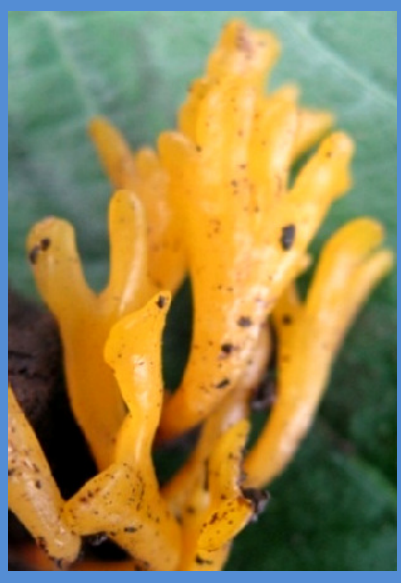

13: Calocera sp. 
International Journal of Researches in

September 2013

ISSN No. (Online): Biosciences, Agriculture \& Technology Issue-1, Volume-1

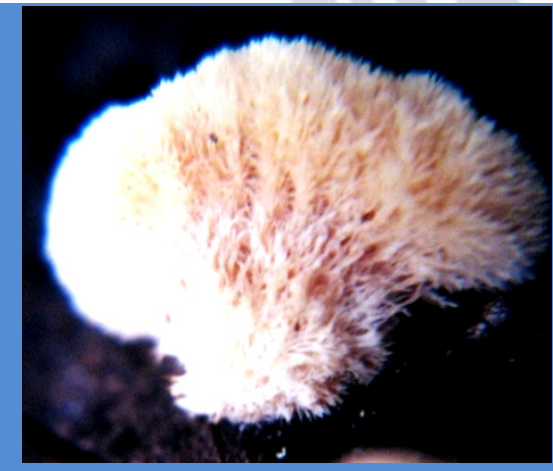

14: Hericium sp.

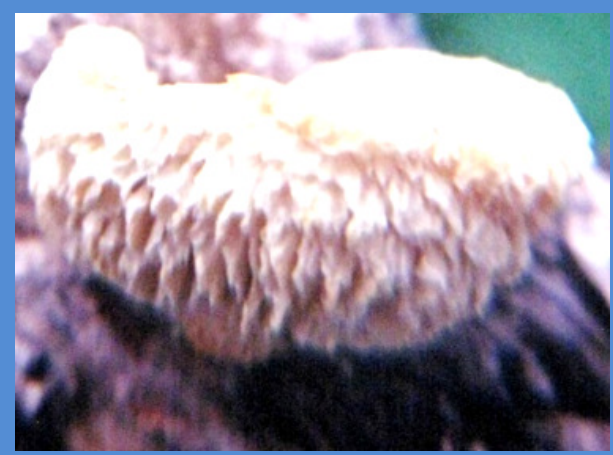

14': Hericium sp.

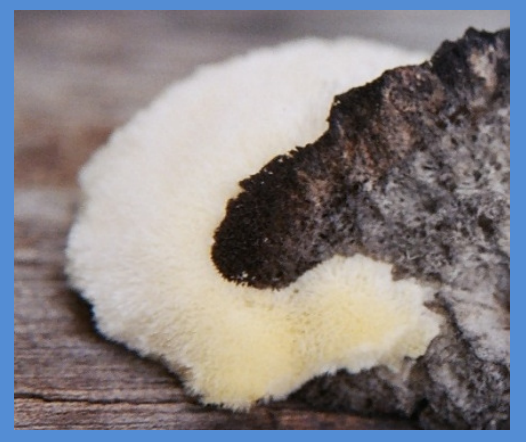

15: Hericium sp.
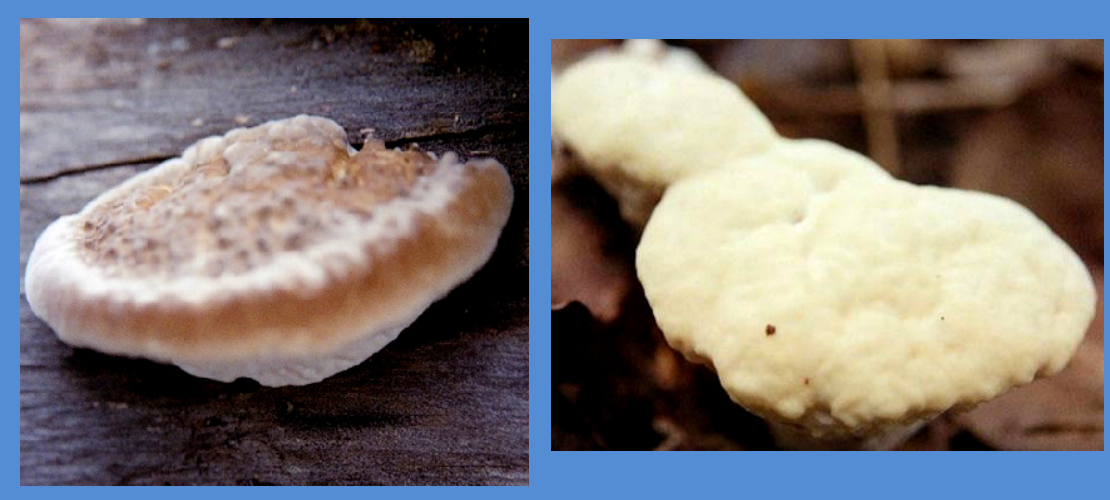

17: Pycnoporus sp.

\section{6: Hydnellum peckii}

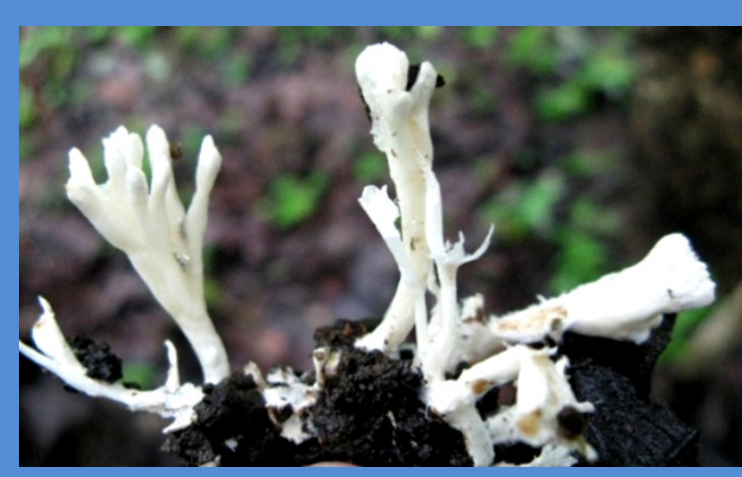

19: Clavulina cristata

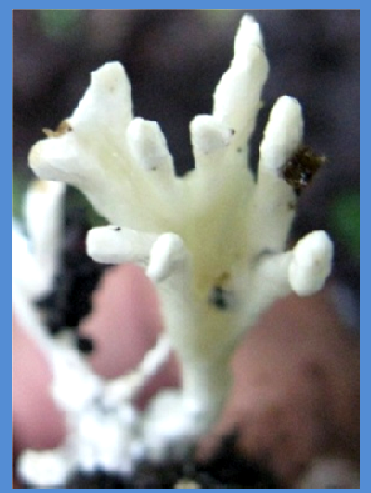

20: rugosa
18: Pycnoporus sp.

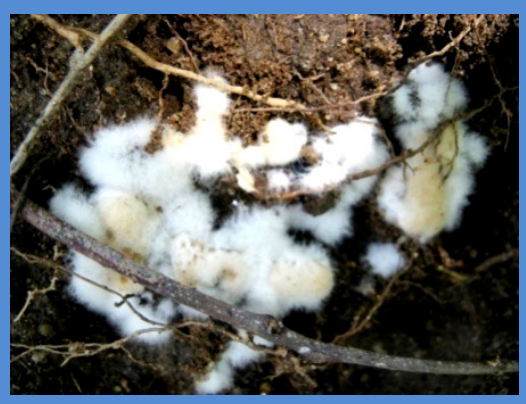

Clavulina

21: unknown 
International Journal of Researches in

September 2013

Biosciences, Agriculture \& Technology

Issue-1, Volume-1

ISSN No. (Online):
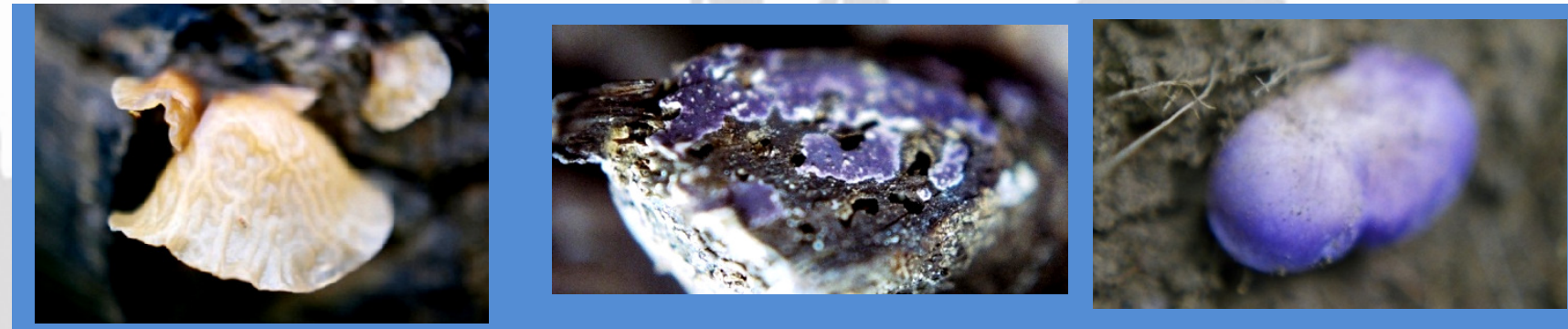

22:Auricularia

\section{3: caeruleum \\ Pulcherricium}

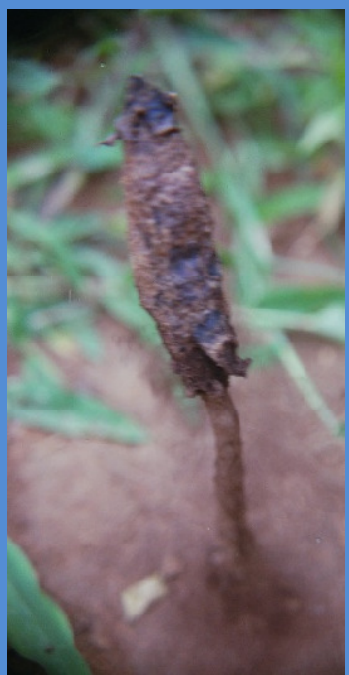

26: Podaxis pistillaris

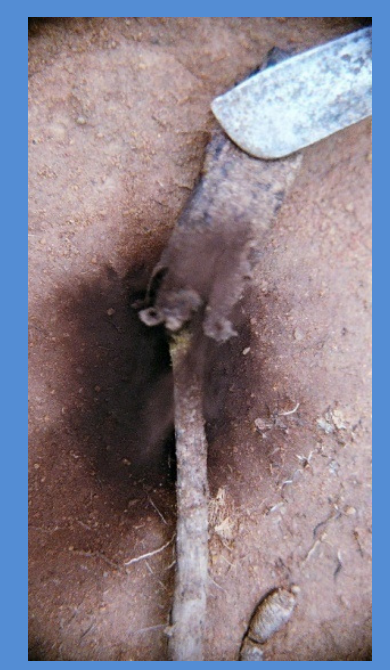

27: Podaxis pistillaris
25: Lapiota Cristata

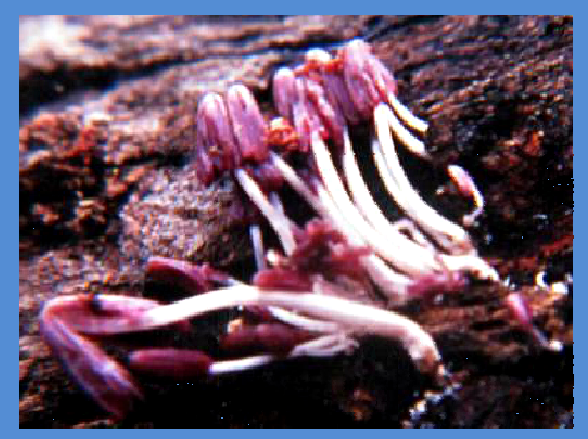

28: Gastrocybe sp.

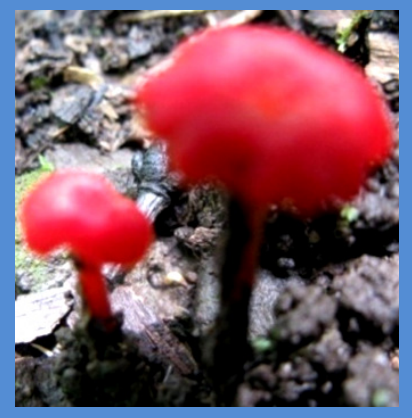

29: Hygrocybe coccineocrenata

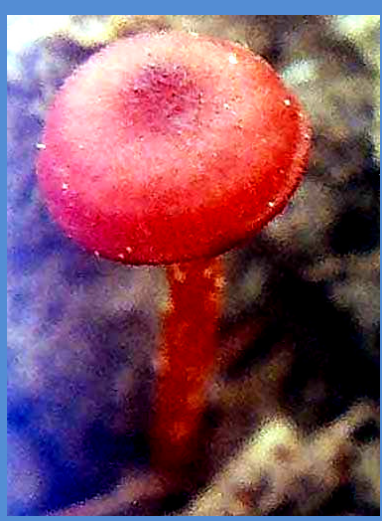

30: coccinea

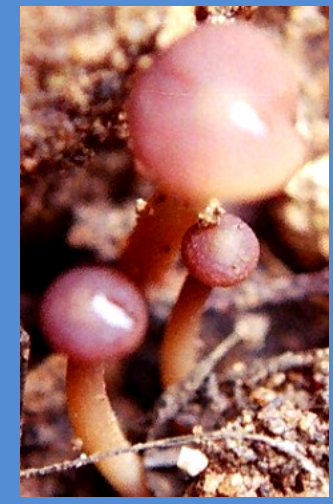

31: Hygrocybe sp. 


\section{RESULTS AND DISCUSSION:}

About seventy five species of the Basidiomycetes fungi are recorded from this area (Table N0.1) Some of the prominent species includes - Clitocybe dicolour, Agaricus spp., Lepiota cristata, Coprinus comatus, Clavaria sp. Geastrum fimbriatum., Hygrocybe coccinea, Schizophyllum commune, Cyathus striatus, Polyporus mori, P. squamosus, Ganoderma, Marasmiellus rameallis, Lycoperdon sp. Oudemansiella spp; Pleurotus sp; Cotrinarius sp; Cantharellus, etc. selected area shows indication of presence of all groups like Polypores e.g. Polyporus spp., Schyzophyllum commune. Gill fungi e.g. Mycena, Marasmius, Hygrocybe, Lapiota sp; Shelf -like hard fungi without pores e.g. Trametes sp, Phellinus sp., Coral fungi e.g. Ramaria sp., Sparassis crespa; Club fungi, Earth stars e.g Geastrum, Gelly fungi e.g. Tremella. Cup fungi e.g. Cyathus, Bovists like Lycoperdon are also recorded, (Plate 1). Some of the morphologically interesting fungi are Auricularia auriculajudae, Clavulina cristata, Clavulina rugosa, Cyathus striatus, Geastrum fimbriatum, Hericium sp., Hydnellum peckii, Hygrocybe coccinea, Lapiota Cristata, Microtyphula sp, Mutinus caninus, Phallus indusiata, Pulcherricium caeruleum, Sparassis crispa, Tremella mesenterica, Tulostoma brumale, etc. Many of fungi shows remarkable variation in its form reveals that Basidiomycetes fungi are among one of the unique class represented in large numbers as well as diversity in forms. Nagpur district in the state of Maharashtra in India which comes under the condition of dry deciduous forest is good reservoir of economically and medicinally important Basidiomycetes fungi which are not explore much need thorough investigation. 
International Journal of Researches in Biosciences, Agriculture \& Technology

\section{REFERENCE:}

Blackwell et al (2006). Mycologia. 98:829

Garnweidner E. (1996). Mushroom and Toadstuls.Publ. Harper Coollins. 253.

Gu C. Q. et al (2007). PubMed. EPub. 75(3):250-7

Hebbett et al (2007) Mycological Research. R: 111: 509

Pacioni G. (1981). Mushroom. Publ. Simon andSchuter. N. York. P. 506

Parino, F. et al (1999). Antivir. Res. 43, 67-78,

Pegler D. and Spooner B. (1992). Grange Book. 144.

Rinaldi A. and Tyndalo V. (1974). Crescent book. N. York.310.
ISSN No. (Online): 